\title{
Synthesis and Analgesic Activity of Novel Derivatives of 1,2-Substituted Benzimidazoles
}

\author{
Shobhit Srivastava, S. N. Pandeya, Meena K. Yadav, and B. K. Singh \\ Department of Pharmaceutical Chemistry, Saroj Institute of Technology \& Management, Lucknow, UP 226002, India
}

Correspondence should be addressed to Shobhit Srivastava; shobhit_pharma@yahoo.co.in

Received 29 January 2012; Revised 20 May 2012; Accepted 31 May 2012

Academic Editor: Gabriel Navarrete-Vázquez

Copyright (c) 2013 Shobhit Srivastava et al. This is an open access article distributed under the Creative Commons Attribution License, which permits unrestricted use, distribution, and reproduction in any medium, provided the original work is properly cited.

A series of novel 2-phenylhydrazinomethyl and 2-(2-hydroxyphenyl)-benzimidazole derivatives substituted at the N1-position of benzimidazole nucleus were synthesized as well as screened for analgesic activity. Some of these compounds showed promising analgesic activity when compared with the standard drug diclofenac sodium. The incorporation of a phenylhydrazinomethyl nucleus at 2-position of benzimidazole compound gave a biologically active pharmacophore.

\section{Introduction}

Benzimidazole derivatives are well-known biologically active $\mathrm{N}$-containing heterocycles [1], widely used as drugs such as proton pump inhibitor (Omeprazole [2,3]), antihelmenthetic (Albendazole $[4,5]$ ), antidopaminergic (Domperidone [6, $7]$ ), and antipsychotic agent (Pimozide). Specifically, the 2substituted analogs of benzimidazoles are known to be potent biologically active compounds [8-10]. Moreover, benzimidazole derivatives are structural isosteres of naturally occurring nucleotides, which allows them to interact easily with the biopolymers of the living systems.

\section{Experimental}

Melting points were determined with an electrothermal melting point apparatus and are uncorrected Table 1. The homogeneity of the synthesized compounds was monitored by thin layer chromatography on Merck Silica Gel precoated plates and visualization was done by exposure to iodine vapour. Unless stated, room temperature was approximately $25^{\circ} \mathrm{C}$. Separation of pure compound was done by column chromatography by using hexane and ethylacetate. ${ }^{1} \mathrm{H}$ NMR was recorded on BRUKER DRX-300 spectrometer (operating at $300 \mathrm{MHz}$ ) using DMSO as solvent. Tetramethyl silane $(0.00 \mathrm{ppm})$ served as an internal standard in ${ }^{1} \mathrm{H}$ NMR. IR spectra were recorded as thin films with a Shimadzu FT-IR spectrophotometer. Elemental analysis was done on Elementar Vario EL III machine at Central Drug Research Institute (CDRI). All the chemicals were commercially purchased from LOBA CHEMIE and were used as received.

2.1. General Procedure for the Synthesis of 2-(Chloromethyl)$1 \mathrm{H}$-benzimidazole. Mixture of o-phenylenediamine $(5.4 \mathrm{~g}$, $0.05 \mathrm{~mol})$, chloroacetic acid $(7.1 \mathrm{~g}, 0.08 \mathrm{~mol})$, and $4 \mathrm{~N}$ hydrochloric acid $(17.17 \mathrm{~mL})$ was heated at reflux for 45 minutes (Scheme 1). The mixture was allowed to stand overnight, filtered, diluted with $100 \mathrm{~mL}$ of distilled water, cooled, and carefully neutralized with $6 \mathrm{~N}$ ammonium hydroxide solution. The solution was kept cold during the neutralization and stirred vigorously to prevent the formation of gums. Product formed was filtered, washed well with cold water and then was placed in vacuum desiccators until dry [11-13]. Recrystallization was done using ethyl alcohol. Yield: $4 \mathrm{~g}$ (48\%), MP: $160-162^{\circ} \mathrm{C}$, Rf: 0.33; IR(KBr) cm ${ }^{-1}: 3150(\mathrm{CH}$, str, ar), 2976(CH, str, ali), 3320(-NH, str), 1657(C=N, str), 492(C=C, str), 787(C-Cl, str); elemental analysis (\%) (calculated/found): 


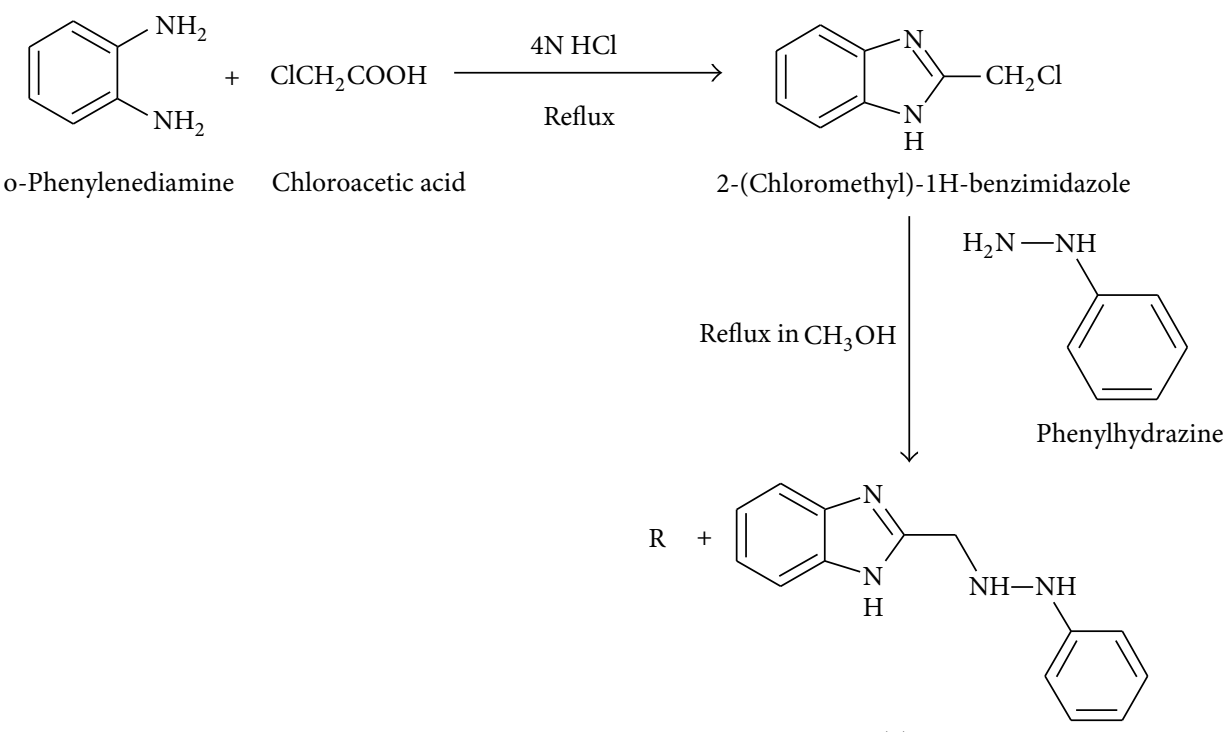

(1)

2-[(2-Phenylhydrazinyl)methyl]-1H-benzimidazole

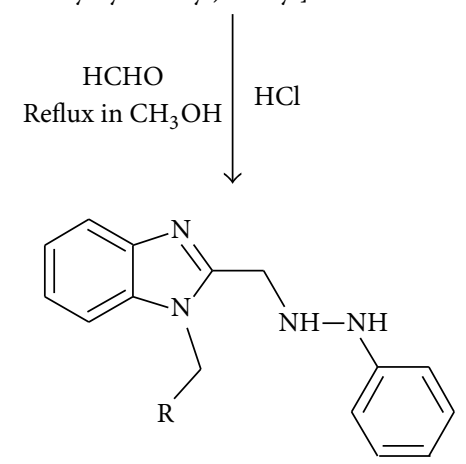

$\begin{array}{ll}\text { Compounds Secondary amines } & \text { Dibsthylamine } \\ \text { la } & \text { Piperidine } \\ \text { 1c } & \text { Morpholine } \\ \text { 1e } & \text { Dimethylamine }\end{array}$


TABLE 1: Physicochemical data for synthesized compounds.

\begin{tabular}{lcccccc}
\hline Compound code & Molecular formula & Molecular weight & Yield (\%) & Melting point $\left({ }^{\circ} \mathrm{C}\right)$ & Rf value & Solubility in DMSO \\
\hline la & $\mathrm{C}_{20} \mathrm{H}_{27} \mathrm{~N}_{5}$ & 337.46188 & 92.0 & $120-122$ & 0.44 & soluble \\
$1 \mathrm{~b}$ & $\mathrm{C}_{20} \mathrm{H}_{26} \mathrm{~N}_{6}$ & 350.46064 & 73.0 & $183-185$ & 0.19 & soluble \\
$1 \mathrm{c}$ & $\mathrm{C}_{21} \mathrm{H}_{27} \mathrm{~N}_{5}$ & 349.47258 & 23.0 & $218-220$ & 0.29 & soluble \\
$1 \mathrm{~d}$ & $\mathrm{C}_{20} \mathrm{H}_{25} \mathrm{~N}_{5} \mathrm{O}$ & 351.4454 & 43.0 & $118-120$ & 0.24 & soluble \\
$1 \mathrm{e}$ & $\mathrm{C}_{18} \mathrm{H}_{23} \mathrm{~N}_{5}$ & 309.40872 & 37.50 & $230-232$ & 0.31 & soluble \\
2 & $\mathrm{C}_{18} \mathrm{H}_{20} \mathrm{~N}_{4} \mathrm{O}$ & 308.3776 & 22.0 & $238-240$ & 0.39 & soluble \\
\hline
\end{tabular}

Eluants for TLC were ethyl acetate: benzene (1:4).

C(57.67/57.27); $\mathrm{H}(4.23 / 3.83) ; \mathrm{Cl}(21.28 / 20.88) ; \mathrm{N}(16.81 /$ 17.21); ${ }^{1} \mathrm{H}$ NMR (DMSO-d6): $\delta$ ppm $5.0(1 \mathrm{~s}, 1 \mathrm{H}, \mathrm{N}-\mathrm{H})$, 7.7(m, 2H, Ar-CH), 4.6(s, 2H, CH2-Cl).

\subsection{Procedure for the Synthesis of 2-[(2-Phenylhydrazinyl)} methyl]-1H-benzimidazole(1) (Scheme 1). A mixture of the above synthesized substituent ( 0.02 mole) and phenylhydraazine $(0.0217$ mole) was heated at reflux in methanol for 5 hours. The hot mixture was poured in crushed ice with constant stirring, the solid was filtered, dried, and recrystal-lized from absolute ethanol [14]. Yield: $2.0 \mathrm{~g}$ (40\%); MP: $80^{\circ} \mathrm{C}-$ $82^{\circ} \mathrm{C}$; Rf: 0.81; IR(KBr) cm ${ }^{1}: 3053(\mathrm{CH}, \mathrm{str}, \mathrm{ar}), 2978(\mathrm{CH}$, str, ali), 3487, 3350(NH, str), 1655(C=N, str), $1456(\mathrm{C}=\mathrm{C}$, str); elemental analysis(\%) (calculated/found): $\mathrm{C}(70.57 /$ 70.17); H(5.92/5.52); N(23.51/23.11); ${ }^{1} \mathrm{H}$ NMR (DMSO-d6): Sppm 5.0(1s,1H, N-H), 7.7(1s, 2H, Ar-CH), 3.81(1s, $2 \mathrm{H}$, $\left.\mathrm{CH}_{2}-\mathrm{N}\right), 4.0(1 \mathrm{~s}, 1 \mathrm{H}, \mathrm{Ar} \cdot \mathrm{N}-\mathrm{H})$.

\subsection{Procedure for the Preparation of Mannich Bases of (1) with Different Secondary Amines}

(a) Synthesis of $N$-ethyl- $N$-(\{2-[(2-phenylhydrazinyl) methyl]-1H-benzimidazole-1 yl $\}$ methyl) ethanamine (1a): a mixture of compound 1 ( $1 \mathrm{~g}, 0.004 \mathrm{~mol})$, formaldehyde $(5 \mathrm{~mL}, 0.004 \mathrm{~mol})$, diethylamine $(0.5 \mathrm{~mL}$, $0.004 \mathrm{~mol})$, and $\mathrm{HCl}(2 \mathrm{~mL})$ was heated at reflux in methanol for 2.5 hours. The hot mixture was filtered and the filtrate obtained was cooled in cold water [15]. Crystals obtained were separated by filtration and purified by column chromatography and recrystallized from absolute ethanol. Yield: $1.230 \mathrm{~g}$ (92\%); MP: $120^{\circ} \mathrm{C}-122^{\circ} \mathrm{C}$; Rf: 0.44; IR(KBr) cm ${ }^{-1}$ : 3040(CH, str, ar), 2978(CH, str, ali), $3320,3405(-\mathrm{NH}$, str), $1557(\mathrm{C}=\mathrm{N}$, str); elemental analysis (\%) (calculated/found): $\mathrm{C}(70.56 / 70.16)$; $\mathrm{H}(7.79 / 7.39) ; \mathrm{N}(21.65 / 21.25) ;{ }^{1} \mathrm{H}$ NMR (DMSO-d6): $\delta$ ppm 7.7(1s, 2H, Ar-CH), 3.81(1s, $\left.2 \mathrm{H}, \mathrm{CH}_{2}-\mathrm{NH}\right)$, $4.0(1 \mathrm{~s}, 1 \mathrm{H}, \mathrm{Ar} \cdot \mathrm{N}-\mathrm{H}), 2.0(1 \mathrm{~s}, 1 \mathrm{H}, \mathrm{N}-\mathrm{H}), 1.0(1 \mathrm{~s}, 6 \mathrm{H}$, $\mathrm{CH} 3)$.

(b) Synthesis of 2-[(2-phenylhydrazinyl)methyl]-1-(piperazin-1-ylmethyl)-1H-benz-imidazole $1 \mathrm{~b}$ ): a mixture of compound $1(1 \mathrm{~g}, 0.004 \mathrm{~mol})$, formaldehyde $(5 \mathrm{~mL}, 0.004 \mathrm{~mol})$, piperazine $(360 \mathrm{mg}, 0.004 \mathrm{~mol})$, and $\mathrm{HCl}(2 \mathrm{~mL})$ was heated at reflux in methanol for 3 hours. The hot mixture was filtered and the filtrate obtained was cooled in cold water. Crystals obtained were separated by filtration and purified by coloumn chromatography and recrystallized from absolute ethanol. Yield: $0.950 \mathrm{~g}$ (73\%); MP: $183^{\circ} \mathrm{C}-185^{\circ} \mathrm{C}$; Rf: 0.19; IR( $\left.\mathrm{KBr}\right) \mathrm{cm}^{-1}: 3180(\mathrm{CH}$, str, ar), 2979(C H, str, ali), 3358, 3340(-NH, str), $1667(\mathrm{C}=\mathrm{N}$, str), $1250(-\mathrm{CN}$, str); elemental analysis (\%) calculated/found: $\mathrm{C}(67.83 / 67.43) ; \mathrm{H}(7.19 / 7.59)$; $\mathrm{N}(16.45 / 16.05) ;{ }^{1} \mathrm{H}$ NMR (DMSO-d6) spectra: $\delta \mathrm{ppm}$ 2.0(1s,1H,N-H), 7.7(1s, 4H, Ar-CH), 3.81(1s, $2 \mathrm{H}$, $\left.\mathrm{CH}_{2}-\mathrm{N}\right), 4.0(1 \mathrm{~s}, 1 \mathrm{H}, \mathrm{Ar} \cdot \mathrm{N}-\mathrm{H}), 2.0(1 \mathrm{~s}, 1 \mathrm{H}$, amine $\mathrm{N}-\mathrm{H}$ )

(c) Synthesis of 2-[(2-phenylhydrazinyl)methyl]-1-(piperidin-1-ylmethyl)-1-Hbenzimidazole (1c): a mixture of compound 1 ( $1 \mathrm{~g}, 0.004 \mathrm{~mol})$, formaldehyde $(5 \mathrm{~mL}, 0.004 \mathrm{~mol})$, piperidine $(0.42 \mathrm{~mL}, 0.004 \mathrm{~mol})$, and $\mathrm{HCl}(2 \mathrm{~mL})$ was heated at reflux in methanol for 3 hours. The hot mixture was filtered and the filtrate obtained was cooled in cold water. Crystals obtained were separated by filtration. The residue was separated. Yield: $0.300 \mathrm{~g}$ (23\%); MP: $218^{\circ} \mathrm{C}-220^{\circ} \mathrm{C}$; Rf: 0.38; IR(KBr) cm ${ }^{-1}$ : 3252(CH, str, ar), 2976 (CH, str, ali), 3380, 3410 (-NH, str), $1658(\mathrm{C}=\mathrm{N}$, str), $1205(-\mathrm{CN}$, str); elemental analysis (\%) calculated/found: $\mathrm{C}(71.61 / 71.21) ; \mathrm{H}(7.51 / 7.11)$; $\mathrm{N}(20.88 / 20.48) ;{ }^{1} \mathrm{H}$ NMR (DMSO-d6) spectra: $\delta$ ppm 2.0(1s, 1h, N-H), 7.7(1s, 4H, Ar-CH), 3.81(1s, 2H, $\mathrm{CH} 2-\mathrm{N}), 4.0(1 \mathrm{~s}, 1 \mathrm{H}, \mathrm{Ar} \cdot \mathrm{N}-\mathrm{H}), 1.05(1 \mathrm{~s}, 4 \mathrm{H}$, amine $\left.\mathrm{CH}_{2}\right), 4.08\left(1 \mathrm{~s}, 2 \mathrm{H}\right.$, meth $\left.\mathrm{CH}_{2}\right)$.

(d) Synthesis of 1-(morpholin-4-ylmethyl)-2-[(2 phenylhydrazinyl) methyl]-1H-benzimidazole (1d): a mixture of compound $1(1 \mathrm{~g}, 0.004 \mathrm{~mol})$, formaldehyde (5 mL, $0.004 \mathrm{~mol})$, morpholine $(0.37 \mathrm{~mL}, 0.004 \mathrm{~mol})$, and $\mathrm{HCl}(2 \mathrm{~mL})$ was heated at reflux in methanol for 3 hours. The hot mixture was filtered and the filtrate obtained was cooled in cold water. Crystals obtained were separated by filtration and purified by column chromatography and recrystallized by absolute ethanol. Yield: $0.550 \mathrm{~g}$ (43\%); MP: $118^{\circ} \mathrm{C}-120^{\circ} \mathrm{C}$; Rf: 0.24 ; IR(KBr) cm ${ }^{-1}: 3150(\mathrm{CH}, \mathrm{str}, \mathrm{ar}), 2980(\mathrm{CH}, \mathrm{str}$, ali), 3310(-NH, str), 1657(C=N, str), 1620(C-O, str), 1240 (-CN, str); elemental analysis (\%) calculated/ found: $\mathrm{C}(67.63 / 67.23) ; \mathrm{H}(6.87 / 6.47) ; \mathrm{N}(20.76 / 20.36)$; ${ }^{1} \mathrm{H}$ NMR (DMSO-d6) spectra: $\delta \mathrm{ppm} \quad 2.0(1 \mathrm{~s}, 1 \mathrm{H}$, 


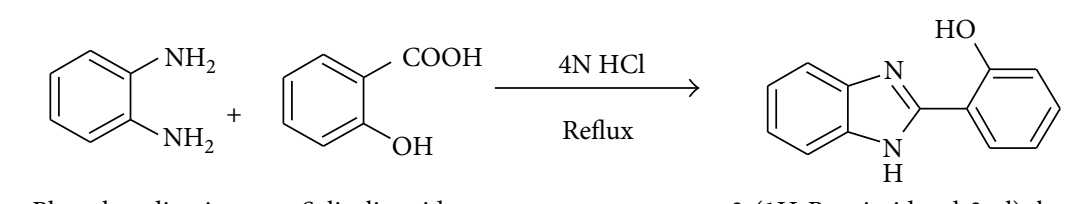

o-Phenylenediamine Salicylic acid

2-(1H-Benzimidazol-2-yl)phenol<smiles>CC(O)CC(C)O</smiles><smiles>Oc1ccccc1-c1nc2ccccc2n1CN1CCNCC1</smiles>

2-[1-(Piperazin-1-ylmethyl)-1H-benzimidazol-2-yl]phenol

(2)

SCHEME 2

$\mathrm{N}-\mathrm{H}), 7.2(\mathrm{~m}, 4 \mathrm{H}, \mathrm{Ar}-\mathrm{CH}), 3.81\left(1 \mathrm{~s}, 2 \mathrm{H}, \mathrm{CH}_{2}-\mathrm{N}\right)$, 4.0(1s, $1 \mathrm{H}, \mathrm{Ar} \cdot \mathrm{N}-\mathrm{H}), 3.6(1 \mathrm{~s}, 4 \mathrm{H}$, amine $\mathrm{O}-\mathrm{CH})$.

(e) Synthesis of N,N-dimethyl-1-\{2-[(2-phenylhydrazinyl)methyl]-1H-benzimidazol-1-yl\}methanamine (1e): a mixture of compound $1(1 \mathrm{~g}, 0.004 \mathrm{~mol})$, formaldehyde $(5 \mathrm{~mL}, 0.004 \mathrm{~mol})$, dimethylamine $(0.21 \mathrm{~mL}, 0.004 \mathrm{~mol})$, and $\mathrm{HCl}(2 \mathrm{~mL})$ was heated at reflux in methanol for 3 hours. The hot mixture was filtered and the filtrate obtained was cooled in cold water [16]. Crystals obtained were separated by filtration and purified by coloumn chromatography and recrystallized by absolute ethanol. Yield: $0.450 \mathrm{~g}(37.5 \%)$; MP: $230^{\circ} \mathrm{C}-232^{\circ} \mathrm{C}$; Rf: 0.29; IR(KBr) cm $\mathrm{cm}^{-1}$ : 3180(CH, str, ar), $2978(\mathrm{CH}$, str, ali), 3350( $-\mathrm{NH}$, str $), 1658(\mathrm{C}=\mathrm{N}$, str); elemental analysis (\%) calculated/found: $\mathrm{C}(69.12 / 69.57)$; $\mathrm{H}(7.17 / 7.57)$; N(23.71/23.31); ${ }^{1} \mathrm{H}$ NMR (DMSO-d6) spectra: $\delta$ ppm $2.0(1 \mathrm{~s}, 1 \mathrm{H}, \mathrm{N}-\mathrm{H}), 7.2(\mathrm{~m}, 4 \mathrm{H}, \mathrm{Ar}-\mathrm{CH})$, 3.81(1s, $\left.2 \mathrm{H}, \mathrm{CH}_{2}-\mathrm{N}\right), 4.0(1 \mathrm{~s}, 1 \mathrm{H}, \mathrm{Ar} \cdot \mathrm{N}-\mathrm{H}), 2.27(1 \mathrm{~s}$, $6 \mathrm{H}$, amine $\mathrm{N}-\mathrm{CH}_{3}$ ).

2.4. Procedure for the Synthesis of 2-(1H-benzimidazol-2-yl) phenol (Scheme 2). A mixture of o-phenylenediamine $(2.70 \mathrm{~g}, 0.05 \mathrm{~mol})$, salicylic acid $(3.55 \mathrm{~g}, 0.05 \mathrm{~mol})$, and $4 \mathrm{~N}$ hydrochloric acid $(25 \mathrm{~mL})$ was heated at reflux for 5 hours. The completion of the reaction was monitored through TLC. The mixture was allowed to stand over-night, filtered, diluted with $50 \mathrm{~mL}$ of distilled water, cooled, and carefully neutralized with $6 \mathrm{~N}$ ammonium hydroxide solution. The solution was kept cold during the neutralization and stirred vigorously to prevent the formation of gums. Product formed was filtered, washed well with cold water, and then was placed in vacuum desiccator until dry [17]. Yield:3.20 g (32\%); MP: $208^{\circ} \mathrm{C}-210^{\circ} \mathrm{C}$; Rf: 0.24; IR(KBr) cm ${ }^{-1}: 3180$ (CH, str, ar), 3310 ( $-\mathrm{NH}$, str), 1657(C=N, str), 3404(OH, str); elemental analysis (\%) calculated/found: $\mathrm{C}(74.27 / 74.67) ; \mathrm{H}(4.79 / 4.39)$; $\mathrm{N}(13.3313 .73) ;{ }^{1} \mathrm{H}$ NMR (DMSO-d6) spectra: $\delta \mathrm{ppm} 5.0(1 \mathrm{~s}$, $1 \mathrm{H}, \mathrm{N}-\mathrm{H}), 7.7(1 \mathrm{~s}, 2 \mathrm{H}, \mathrm{Ar}-\mathrm{CH}), 5.1(1 \mathrm{~s}, \mathrm{OH})$.

2.5. Synthesis of 2-(1-Piperazin-1-ylmethyl-1H-benzoimidazol2-yl)-phenol (2). a mixture of the above synthesized compound $(1 \mathrm{~g}, 0.004 \mathrm{~mol})$, formaldehyde $(5 \mathrm{~mL}, 0.004 \mathrm{~mol})$, piperazine $(0.410 \mathrm{~g}, 0.004 \mathrm{~mol})$ and $\mathrm{HCl}(2 \mathrm{~mL})$ was heated at reflux in methanol for 3 hours. The hot mixture was filtered and cooled in cold water. Crystals obtained were separated by filtration and purified by coloumn chromatography and recrystallized by absolute ethanol. Yield: $0.300 \mathrm{~g}$ (22\%); MP: $238^{\circ} \mathrm{C}-240^{\circ} \mathrm{C}$; Rf: 0.39; IR(KBr) $\mathrm{cm}^{-1}: 3158(\mathrm{CH}$, str, ar), 2978(CH, str, ali), 3340(-NH, str), 1668(C=N, str), $3347(\mathrm{OH}, \mathrm{str}), 1278(-\mathrm{CN}$, str); elemental analysis (\%) calculated/found: $\mathrm{C}(70.11 / 70.51) ; \mathrm{H}(6.54 / 6.94) ; \mathrm{N}(18.17 / 18.37)$; ${ }^{1} \mathrm{H}$ NMR(DMSO-d6): ${ }^{1} \mathrm{H}$ NMR(DMSO-d6): $\delta$ ppm 1.2(s, 2H, $\left.\mathrm{CH}_{2}\right), 3.4(\mathrm{~s}, 1 \mathrm{H}$, Pipera-H), 9.83(s, O-H), 7.4(t, 4H, ar-H).

2.6. Biological Activity (Analgesic Activity by Acetic Acid Induced Writhing Test). Analgesic activity was determined by calculating total number of writhings, followed by intraperitoneal (IP) administration of $0.6 \%(0.1 \mathrm{~mL} / 10 \mathrm{~g})$ acetic acid in mice. 7 Albino mice of either sex $(25-30 \mathrm{~g})$ were used. Synthesized compounds (1a, 1b, 1c, 1d, 1e, 2) were administered 
TABLE 2: Acetic-acid-induced writhing response in mice.

\begin{tabular}{|c|c|c|c|c|}
\hline S. no. & Derivative & Dosage & No. of writhings in 20 min (mean \pm S.E.M) & $\%$ Analgesic activity $^{*}$ \\
\hline 1 & Control & Vehicle & $75.66 \pm 2.15$ & 0 \\
\hline 2 & 1a & $20 \mathrm{mg} / \mathrm{kg}$ & $19.00 \pm 1.84$ & $74.88^{* *}$ \\
\hline 3 & $1 b$ & $20 \mathrm{mg} / \mathrm{kg}$ & $33.66 \pm 1.83$ & $55.51^{* *}$ \\
\hline 4 & $1 \mathrm{c}$ & $20 \mathrm{mg} / \mathrm{kg}$ & $33.33 \pm 1.27$ & $55.94^{* *}$ \\
\hline 5 & $1 \mathrm{~d}$ & $20 \mathrm{mg} / \mathrm{kg}$ & $26.83 \pm 1.41$ & $64.53^{* *}$ \\
\hline 6 & $1 \mathrm{e}$ & $20 \mathrm{mg} / \mathrm{kg}$ & $23.33 \pm 2.00$ & $69.16^{* *}$ \\
\hline 7 & 2 & $20 \mathrm{mg} / \mathrm{kg}$ & $22.83 \pm 1.42$ & $70.12^{* *}$ \\
\hline 8 & Diclofenac & $20 \mathrm{mg} / \mathrm{kg}$ & $08.16 \pm 0.85$ & $89.21^{* * *}$ \\
\hline
\end{tabular}

$N=6$; Student's $t$-test;

${ }^{*} P \leq 0.05$;

${ }^{* *} P \leq 0.01$

${ }^{* * *} P \leq 0.0001$ when compared with control.

IP $(0.5 \mathrm{~mL})$ as a suspension in sterile $0.9 \%$ DMSO solution as vehicle. Diclofenac $(10 \mathrm{mg} / \mathrm{kg})$ was used as the standard drug under same conditions. Acetic acid solution was administered IP $30 \mathrm{~min}$ after administration of the compounds. 10 min after intraperitoneal injection of acetic acid solution, the number of writhings per animal was recorded for $20 \mathrm{~min}$. Control animals received an equal volume of vehicle [17]. Results of percentage Analgesic activity of compounds was calculated using the following formula and the results are shown in Table 2:

$$
\% \text { Analgesic activity }=\frac{\text { No. of writhings for control }- \text { No. of writhings for test compound }}{\text { No. of writhings for control }} * 100 \text {. }
$$

\section{Results and Discussion}

The series of above synthesized compounds (1a, 1b, 1c, 1d, 1 e, 2) in Table 1 were evaluated for analgesic activity by acetic-acid-induced writhing test in vivo on albino mice. Diclofenac sodium was used as the standard drug in abovecited test. In Table 2 The compounds (1a, 2) showed good activity and compounds (1b, 1c, 1d, 1e) showed moderated activity when compared with the standard drug. Compound la was almost equal in activity to the standard drug diclofenac and was considered the lead molecule. The results were evaluated by measuring the mean \pm S.E.M and $P$ value. Thus, 2 -substitution of phenylhydrazinomethyl on benzimidazole moiety and use of different secondary amines for preparation of Mannich bases at N1 of 2-substituted benzimidazole ring increases the compound's activity against peripheral analgesia.

\section{Conclusion}

The present work has clearly demonstrated that 2chloromethylbenzimidazole moiety may be successfully used to synthesize a wide variety of benzimidazole derivatives of pharmaceutical interest. Moreover, in general the desired compounds are obtained in a single step with clean high yields. Six derivatives of 2-substituted benzimidazole were prepared out of that compounds $1 \mathrm{a}$ and 2 possess potent analgesic activity as shown in the acetic-acid-induced writhing test. Hence, the focus is on the synthesis of potent 1,2-substituted benzimidazole derivatives as potential druglike scaffolds for future development.

\section{References}

[1] A. Kozo, A. Kazuhiro, K. Masayuki, and Y. Yonhzhe, Chemical Abstract, vol. 134, article 86247, 2001.

[2] J. E. Baldwin, R. M. Adlington, and N. P. Crouch, Chemical Abstract, vol. 130, article 196655, 1999.

[3] H. D. Langtry and M. I. Wilde, "Omeprazole: a review of its use in Helicobacter pylori infection, gastro-oesophageal reflux disease and peptic ulcers induced by nonsteroidal antiinflammatory drugs," Drugs, vol. 56, no. 3, pp. 447-486, 1998.

[4] J. C. Hazelton, B. Iddon, H. Suschitzky, and L. H. Woolley, " $2 \mathrm{H}$-benzimidazoles (isobenzimidazoles). Part 10. Synthesis of polysubstituted o-phenylenediamines and their conversion into heterocycles, particularly 2 -substituted benzimidazoles with known or potential anthelminthic activity," Tetrahedron, vol. 51, no. 39, pp. 10771-10794, 1995.

[5] C. S. Labaw and R. L. Webb, Chemical Abstract, vol. 95, article 168837, 1981.

[6] L. E. L. Kennis, J. Vandenberk, J. M. Boey et al., "The chemical development of selective and specific serotonin S2-antagonists," Drug Development Research, vol. 8, pp. 133-140, 1986.

[7] M. F. Calvo, Chemical Abstract, vol. 106, article 67314, 1986.

[8] P. N. Preston, "Synthesis, reactions, and spectroscopic properties of benzimidazoles," Chemical Reviews, vol. 74, no. 3, pp. 279-314, 1974.

[9] Z. Kazimierczuk, M. Andrzejewska, J. K. Austova, and V. Klimesova, European Journal of Medicinal Chemistry, vol. 40, pp. 204-208, 2005. 
[10] J. M. Wallace and B. C. Soderberg, "Abstracts of papers," in Proceedings of the 225th National Meeting of the American Chemical Society, 185075, New Orleans, La, USA, 2003.

[11] W. Knobloch, "Pharmakologisch wirksame Benzimidazole, III. Synthese von substituierten Benzimidazolen mit potentieller Antitumorwirkung," Chemische Berichte, vol. 91, no. 12, pp. 2557-2561, 1958.

[12] S. V. Amrutkar, D. B. Umesh, P. Pargharmol, S. S. Kotgire, and M. S. Ranawat, "Synthesis and antifungal activity of 1-alkyl/H2[4-(alkyl/aryl-piperazin-1-yl)-methyl]-benzimidazole derivatives," International Journal of Pharmacy and Pharmaceutical Sciences, vol. 2, no. 2, pp. 84-92, 2010.

[13] H. S. C. Vankataramana, A. Singh, A. Tiwari, and V. Tiwari, International Journal of Pharmaceutical Sciences and Research, vol. 1, no. 37, 2010.

[14] H. S. C. Vankataramana, A. Singh, A. Tiwari, and V. Tiwari, "Synthesis of phenyl hydrazine substituted benzimidazole derivatives and their biological activity," International Journal of Pharmaceutical Sciences and Research, vol. 1, p. 32, 2010.

[15] F. G. Mann and B. C. Saunders, Practical Organic Chemistry, Longman Publication, 4th edition, 2005.

[16] B. S. Furniss and A. J. Hannaford, Practical Organic Chemistry, Longman Publication, 5th edition, 2005.

[17] A. J. Kasabe and P. J. Kasabe, "Synthesis, anti tubercular and analgesic activity evaluation of new 3-pyrazoline derivatives," International Journal of Pharmacy and Pharmaceutical Sciences, vol. 2, no. 2, pp. 132-134, 2010. 

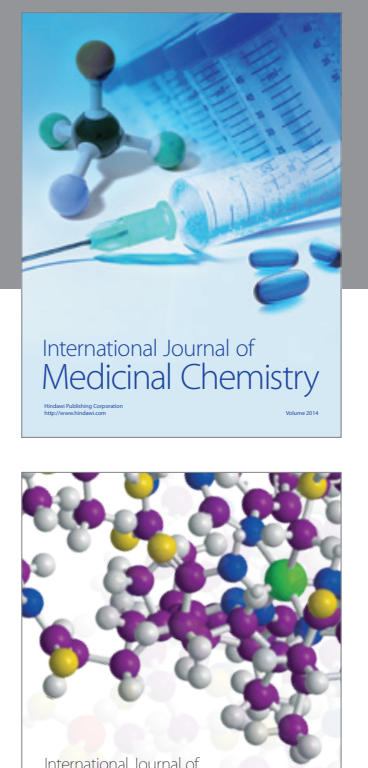

\section{Carbohydrate} Chemistry

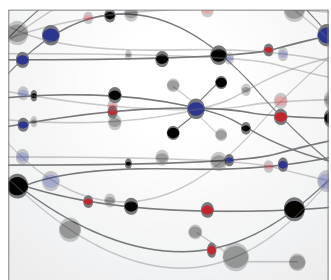

The Scientific World Journal
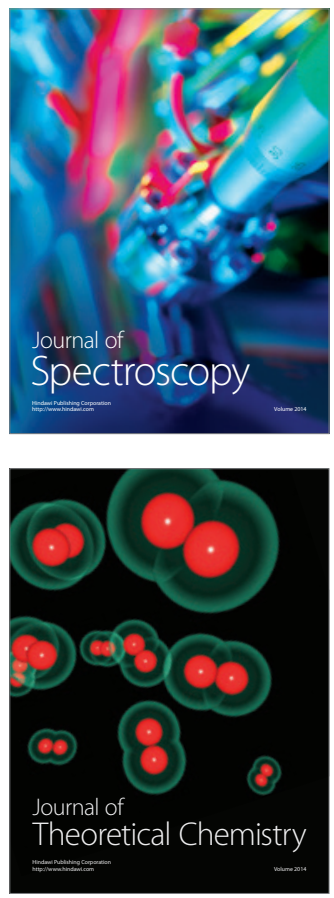
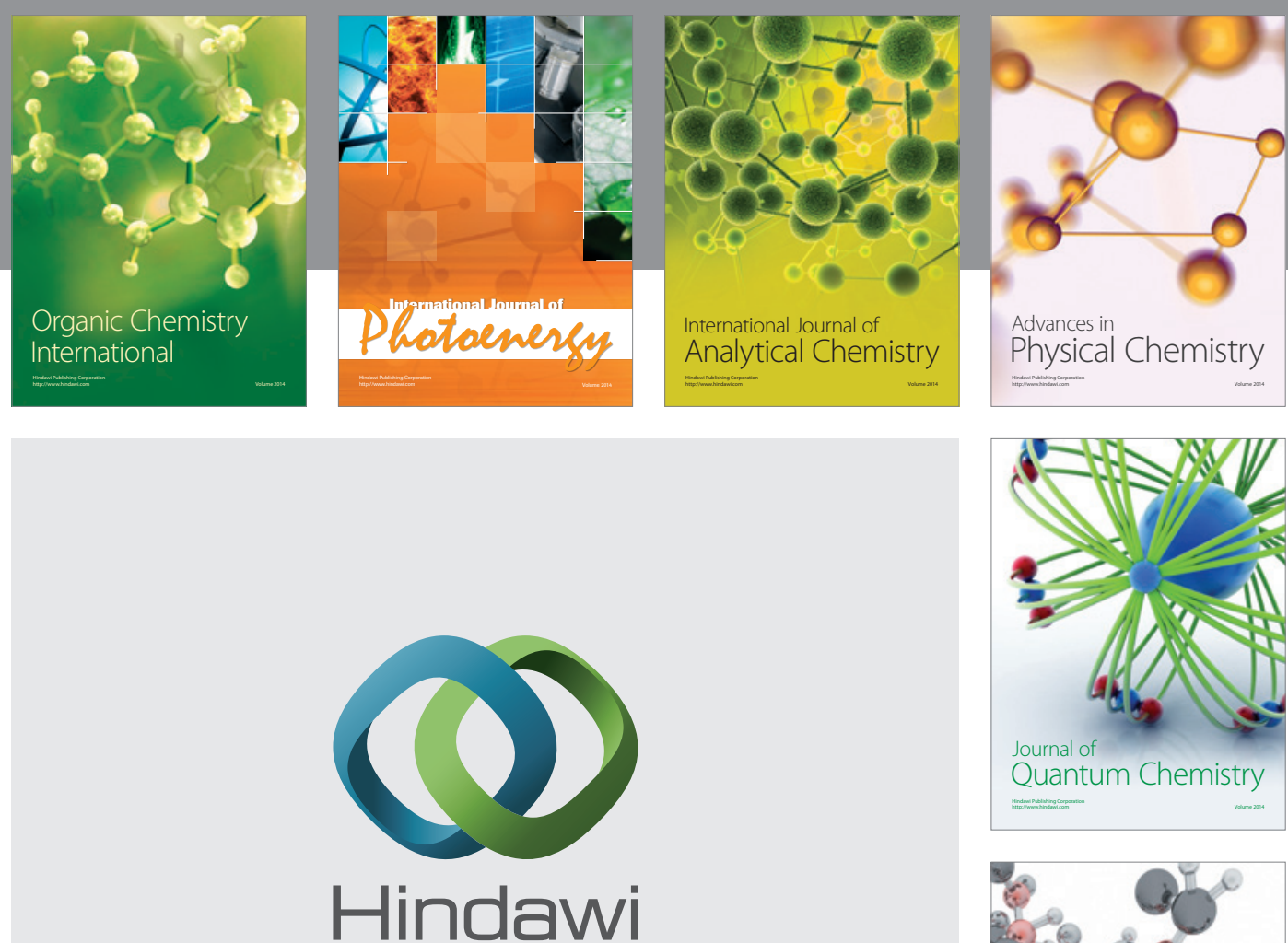

Submit your manuscripts at

http://www.hindawi.com

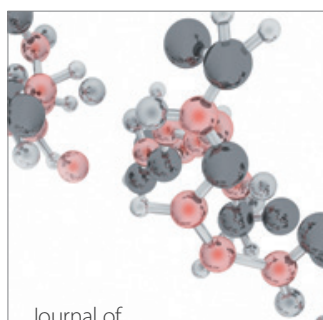

Analytical Methods

in Chemistry

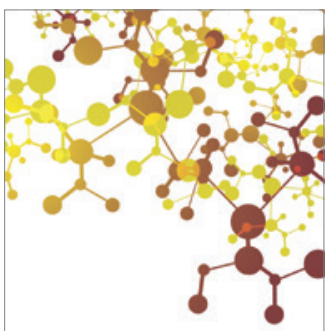

Journal of

Applied Chemistry

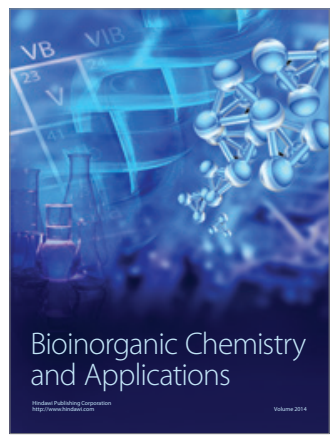

Inorganic Chemistry
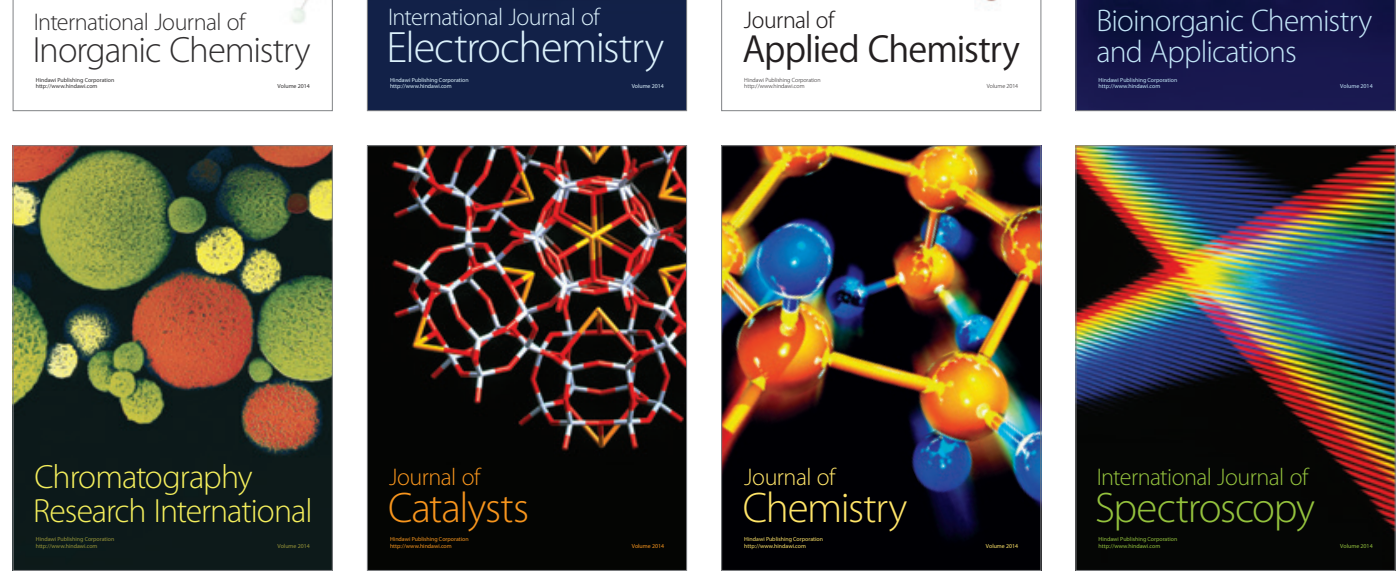